\title{
NANOMEDICINE: will it offer possibilities to overcome multiple drug resistance in cancer?
}

\author{
Sten Friberg ${ }^{1}$ and Andreas M. Nyström ${ }^{2 *}$
}

\begin{abstract}
This review is written with the purpose to review the current nanomedicine literature and provide an outlook on the developments in utilizing nanoscale drug constructs in treatment of solid cancers as well as in the potential treatment of multi-drug resistant cancers. No specific design principles for this review have been utilized apart from our active choice to avoid results only based on in vitro studies. Few drugs based on nanotechnology have progressed to clinical trials, since most are based only on in vitro experiments which do not give the necessary data for the research to progress towards pre-clinical studies. The area of nanomedicine has indeed spark much attention and holds promise for improved future therapeutics in the treatment of solid cancers. However, despite much investment few targeted therapeutics have successfully progressed to early clinical trials, indicating yet again that the human body is complicated and that much more understanding of the fundamentals of receptor interactions, physics of nanomedical constructs and their circulation in the body is indeed needed. We believe that nanomedical therapeutics can allow for more efficient treatments of resistant cancers, and may well be a cornerstone for RNA based therapeutics in the future given their general need for shielding from the harsh environment in the blood stream.
\end{abstract}

Keywords: Cancer chemotherapy, Nanomedicine, Multidrug resistance, Cancer stem cells, Tumor-targeted delivery

\section{Background}

Around $50 \%$ of humans who are diagnosed with a malignant tumor will die from their disease. In 2012, the actual figures for 40 European countries were 3.45 million new registered cases of various cancers and 1.75 million deaths from malignancies. The global incidence and mortality rates are similar [1]. Despite advances in diagnosis and treatment, mortality from cancer still remains high. Approximately $90 \%$ of the recurrences of cancers after the primary general therapy (endocrine as well as chemical) are caused by the genes coding for multiple drug resistance (MDR) [2-9].

Many cancer therapies kill the bulk cells of a tumor but fail to cure the patient because they do not eliminate cancer stem cells (CSCs), [8, 10-22] which survive to generate new tumors. Virtually all anticancer therapies

\footnotetext{
*Correspondence: Andreas.nystrom470@gmail.com

${ }^{2}$ Institute of Environmental Medicine, Karolinska Institutet, Nobels väg 13,

17177 Stockholm, Sweden

Full list of author information is available at the end of the article
}

in use today are designed to target the primary tumors. However, it is usually not the cells in the primary tumor that threaten the life of the patient; it is the metastatic cell population. In the war against cancer, the CSCs and MDR must be mastered. The attacks on the CSCs can be direct (i.e. against the tumor cells) [2-5, 9, 23-25] or indirect (i.e. against in the microenvironment [26-30]) or intended to disrupt the communication between CSCs and the microenvironment [31-37].

Since its discovery in the early 1960 s, nanomedicine has created high expectations, and nanotechnology has been expected to reinforce the current medical armament in clinical oncology. Unfortunately, many of these expectations have not been realized. In this review, we will attempt to analyze the present status of nanooncology. Because some publications on the possibilities for nanomedicine have been overoptimistic and oversimplified, we have devoted ample space to present studies showing the difficulties and obstacles that nanooncology faces. 
In this review we will present:

1. A brief outline of future oncologic treatments of generalized solid malignancies (in contrast to hematologic malignancies)

2. The biological background to the phenomena of MDR and CSCs

3. The factors that affect drug distribution in the human body

4. A short introduction to nanotechnology

5. An overview of some of the hurdles to be overcome by nanomedicines

6. Strategies likely to be employed in future general oncologic treatments

7. An inventory of drugs available today for general oncologic treatment

8. Some clinical results utilizing nanotechnology.

\section{An outline of future oncologic treatment of generalized disease}

CSCs in a metastatic niche (i.e. stationary) are likely to be protected by several cellular shields, and to reach the CSCs these shields have to be removed one by one, like peeling an onion. The general steps in combatting CSCs include inhibition of drug-resistance mechanisms, elimination of the protecting bulk tumor cells, instigation of growth in the quiescent CSCs, and re-education (in this context-inducing differentiation) or elimination of the CSCs [38]. These steps are described in more detail at the end of this publication.

\section{The background to MDR AND CSCs}

\section{Definition of $\mathrm{mdr}$}

MDR can be defined as a state of resistance against structurally and/or functionally unrelated drugs. The tumor cell population becomes resistant not only to the drug that is initially applied, but also becomes cross-resistant to unrelated drugs with different mechanisms of action [28]. The resistance might be intrinsic in the cell (primary) or acquired via mutations (secondary) [39]. MDR is a basic cellular survival mechanism, and many of the genes involved are ubiquitous. During evolution, they have been maintained from unicellular eukaryotes through multicellular organisms. Bacteria use these or similar genes to become resistant to antibiotics, [40-44] insects use them to overcome pesticides, [40-42, 44-46] and cancer cells use them to survive the oncologist's treatments.

\section{Existance of $\mathrm{mdr}$}

There are numerous cellular genes involved in MDR. One of the better known is the ATP binding cassettes (ABC) [47-49], a family of more than 50 genes. Several of them control membrane-bound efflux pumps, capable of expelling molecules against a concentration gradient. Many of them collaborate with four of the major cellular signal chains; WNT, NOTCH, HEDGEHOG (Hgh), and NANOG (See below). Under normal conditions these four signal chains code for proteins involved in organ development. In cancer cells however they drive the cell population to proliferation. What may be benefical to a baby may be disastrous to its parents.

Wnt: 'W' stands for "wingless" in Drosophila. If the wnt signaling pathway is defective during embryogenesis in Drosophila, the flies do not develop wings. In humans, overexpression of proteins in this pathway leads to multiple basal cell carcinomas in the skin [50-53].

NOTCH: Dysfunction in this developmental signaling pathway results in a notch in the wings of Drosophila [53-56]. In humans, a dysregulated $N O T C H$ is involved in the malignant progression of numerous cancers (breast, pancreas, lung, renal, and also malignant melanoma and malignant glioblastoma multiforme).

$H g h$ : If $H g h$ is dysfunctional during embryogenesis, the larvae of Drosophila develop spikes like a hedgehog. In humans, $H g h$ is usually constitutively active in metastatic niches and drives the malignant cell population to proliferate [57-59].

NANOG: The term "NANOG" has nothing to do with the Greek word "nano" meaning dwarf. It is derived instead from a Celtic myth "Tir nan og" meaning "ever young", indicating its role in maintaining CSCs in an embryonically young state. NANOG drives cell proliferation to maintain pluripotency and at the same time blocks differentiation [60-66]. Activation of NANOG is also a survival mechanism for cancer cells to resist the immune system. High expression of NANOG in biopsies from human tumors is correlated with low differentiation, early metastases, and poor prognosis. The collaboration between $W N T, N O T C H, H g h$, and NANOG, drive the malignant cells to become radio resistant, chemo resistant and immune resistant. Their crosstalk can be deadly for the host.

\section{Cancer stem cells (CSCs)}

Populations of both normal cells and cancer cells contain the following four types of cells: resting stem cells, proliferating cells in transit, terminally differentiated cells (which are non-proliferating), and dying cells (apoptotic). Conventional oncologic treatment is directed against the three last components, which constitute the major part of a macroscopic tumor [67].

Even if that therapy is successful, however, the nonproliferating stem cells still remain, and these can instigate proliferation at a later date causing recurrence of the disease [68]. Because these cells are likely 
to be resistant to further treatment, they are usually fatal. There is no unanimous definition of CSCs, but the American Association for Cancer Research defines them as follows: "A cell within a tumor that possesses the capacity to self-renew and to cause the heterogeneous lineages of cancer cells that compromise the tumor" (http://www.aacr.org). CSCs are identified by the expression of markers on the cell surfaces, by sphere formation in 3D cultures, and by the ability to form growing tumors when transplanted into experimental animals (xenotransplantation). The other three cellular components in a tumor cell population are not capable of xenotransplantation. The occurrence and characteristics of CSCs have been described in numerous publications [7, 8, 10-14, 17-22, 67, 69-87].

The analysis of cell surface markers on CSCs is performed in vitro, but whether the same markers are also expressed in vivo is not known. Neither is it known if normal stem cells express cell surface markers similar to those on CSCs $[10,16,19,88]$. There is likely to exist a large overlap in phenotypic characteristics and metabolic regulators between normal stem cells and CSCs, and this makes it extremely difficult to design therapies that selectively affect the malignant cells. This information is of paramount importance; if scientists can construct a therapy directed against the cell surface markers on CSCs, it must be known - without doubt-that similar markers do not exist on normal stem cells. Otherwise, the side effects might be lethal to patients. A further complication is that CSCs are not universal for different types of malignancies. For example, the CSCs in a brain tumor might be very different from those in a cancer emanating from a kidney, and the CSCs in the primary tumor might be different from the CSCs in its metastases. Also, CSC's can differ from one time point to anther in the same tumor cell population. Moreover, the pluripotent CSCs are phenotypically flexible capable of evading the hosts defense mechanisms [67, 84, 89-91].

\section{Characteristics of CSCs}

CSCs are usually rare, and there can be as few as 1 CSC for every $1,000,000$ bulk tumor cells $[10,38]$. This means that CSCs can be difficult to locate because they are hidden in small niches and difficult to identify by any of today's diagnostic methods. In the metastatic niche, the CSCs are:

- Protected by their own offspring (whether these cells are dead or alive)

- Capable of evading apoptosis

- Self-sufficient in growth signals (when the tumor is larger than a critical size)
- Capable of limitless replication and self-renewal. Of the four cellular components in a malignant cell population, only the CSCs have such potential

- Able to evade growth suppressors

- Capable of DNA repair

- In possession of forceful efflux pumps

- Initially avascular, thereby not reachable through the blood at early stages

- Able to sustain angiogenesis (when the tumor is over a certain size)

- Capable of tissue invasion

- Mobile

- Capable of cell fusion

- Able to create various phenotypes

- Quiescent. Therefore, they have no or very low metabolism, similar to hibernating animals or dormant plant seeds. Quiescence or dormancy is a property of several different CSCs $[10,16]$, not only malignant CSCs.

CSCs do not seem to consist of one particular phenotype, but instead appear to represent a plasticity of interchangeable states and a variety of clones. Depending on the selection pressures - which are often epigenetic-one or two clones become dominating in a Darwinian manner. CSCs present an elusive and moving target, defying the hopes of the patient and the efforts of the clinician.

Paradoxically, the host of the malignant cell population facilitates the maintenance of its own enemy: the CSCs. The microenvironment within the host where the CSCs are located not only supports and protects the CSCs, but it also educates the CSCs and instigates MDR. The tumor microenvironment is dominated by the extracellular matrix (ECM) [2, 87, 89, 92-98].

The ECM surrounds almost all somatic cells in higher organisms. It is not only a supportive scaffold but also a dynamic and complex environment that is able to regulate cell behavior. The ECM plays important roles in embryogenesis, cell regulation, and wound healing. The ECM is made up of collagen, elastin, laminin, polysaccharides, and many other biological macromolecules, and the cellular components of the ECM include fibroblasts, macrophages, leucocytes, etc. In cancer patients, the ECM can become deregulated and disorganized in parts of the body, and these regions can harbor metastatic cells in what is known as a metastatic niche $[94,99,100]$. The ECM can even revert mature cancer bulk cells into pluripotent CSCs. The ECM, CSCs, and MDR form an axis of evil, and their cross-talk can be lethal to the host.

\section{Distribution of drugs in the human body}

The distribution of drugs in the human body is governed mainly by vascular transport, transvascular transport, 
and interstitial transport through the ECM [101]. Extensive reviews are found in the following publications [102-113].

\section{Vascular distribution}

The vascular supply in a solid malignant tumor is heterogeneous, and regions of hypoxia, acidity, and necrosis are intermixed with areas of good vascular supply $[114,115]$. No matter where a drug or nanoparticle (NP) is extravasated in a solid tumor they will have difficulties in reaching all regions of that tumor $[62,116]$.

\section{Transvascular distribution (or extravasation)}

In order to reach their targets, all therapeutic agents must leave the blood circulation. This is not an easy task because the pores in the normal endothelium are very narrow. Normal vessels have $2 \mathrm{~nm}$ gaps in capillaries and up to $6 \mathrm{~nm}$ gaps in post-capillary venules. Corresponding pores in the kidneys and the liver are $40-50 \mathrm{~nm}$, and in the spleen they are around $150 \mathrm{~nm}$. The pore size in experimental tumors can vary from 100 to $800 \mathrm{~nm}$. Particles can be entrapped in these fenestrae, creating what is called the enhanced permeation and retention (EPR) effect [117].

\section{Enhanced permeation and retention effect}

The vascular beds in experimental animal models are usually malfunctioning. They are leaky and they allow molecules, and even cells, in the circulation to diffuse into the tumor. The enhanced permeability of the tumor vasculature in combination with lack of adequate lymphatic drainage leads to a prolonged half-life (retention) of the drug in a tumor [117-122]. The EPR effect has been utilized by polymer conjugates, micelles, and other NPs that are usually smaller than $200 \mathrm{~nm}$ in diameter [123, 124]. However, there are doubts about the therapeutic usefulness of EPR in humans. First, there is no standard EPR effect; it is a highly heterogeneous phenomenon varying from one type of tumor to another, from the primary tumor to its metastases, from one part of a tumor to another, and even within the same tumor at different times. Second, most solid tumors develop high interstitial pressure ranging from 5 to $40 \mathrm{mmHg}$ depending on the tumor type and size. Compared to the normal pressure of $<3 \mathrm{~mm} \mathrm{Hg}$, such high pressure can effectively counteract the in-flow of therapeutic agents into the tumor [117-120, 125].

Third, the concept that malignant tumors have leaky and irregular vessels is based on observations in experimental tumors that have been selected for fast growth to save time and money for researchers. This is a general observation for most experimental tumors, whether they are chemically or virally induced. The tumor volume doubling time (TVDT) in many experimental tumors is around 10 days. In humans, however, most malignant tumors are slow growing, often requiring years to reach a size of $1 \mathrm{~cm}^{3}$. The TVDTs for most human malignant tumors fall between 100 and 300 days [126]. Meanwhile, their vessels can develop slowly and be in good anatomical order with adequate lymphatic drainage. Thus, in humans the value of EPR for therapy of solid malignant tumors is doubtful $[120,127]$.

Passive transvascular transport is driven by the concentration gradient of NPs from the efferent vessel toward the environment. This transport is a time-consuming process requiring one to a few hours. NPs have no propulsive force, and wherever they land in a body they arrive there through passive distribution $[120,128]$.

\section{Interstitial transport}

The third mode of distribution concerns molecules as small as oxygen. The interstitium can be vicious and dense, at times very time-consuming to penetrate [128].

All three steps have a profound influence on the distribution of nanomedicines, and these hurdles will be discussed below under the heading "The long journey".

\section{Nanoparticles}

Nanos is the Greek word for "dwarf". Nanotechnology refers to matter with at least one dimension between 1 and $100 \mathrm{~nm}[129,130]$. One nanometre is $10^{-9}$ meters, and a sheet of paper is about 100,000 nm thick. In such a world, materials take on different physical, chemical, and biological properties as a result of their small size. NPs are solid particles with a plethora of sizes, compositions, and characteristics $[131,132]$. They are usually made of lipids, crystals of metals or silicates, proteins, or polymers. NPs can have several structures, and some of the more common ones are depicted in Fig. 1.

NPs can be loaded with drugs, bioactive agents (like genes), or diagnostic tools (like radioactive tracers) [129, 132, 133]. Thus armed, they can serve as vectors inside the body. These vectors can be constructed such that they are activated/dissolved under specific conditions such as acidity, temperature, or light. Such constructs are intended to serve dual purposes of protecting the host from the active agent while it is being transported in the body and protecting the active agent from being excreted by the kidneys, captured by the reticuloendothelial system (macrophages, antibodies, etc.), or degraded by the host's normal metabolism. An example of an oncologic therapy based on NP formulations is given in Fig. 2.

There are numerous well written reviews on the topic of nanomedicine and we point the interested reader to the following [28, 81, 132, 134-161]. 


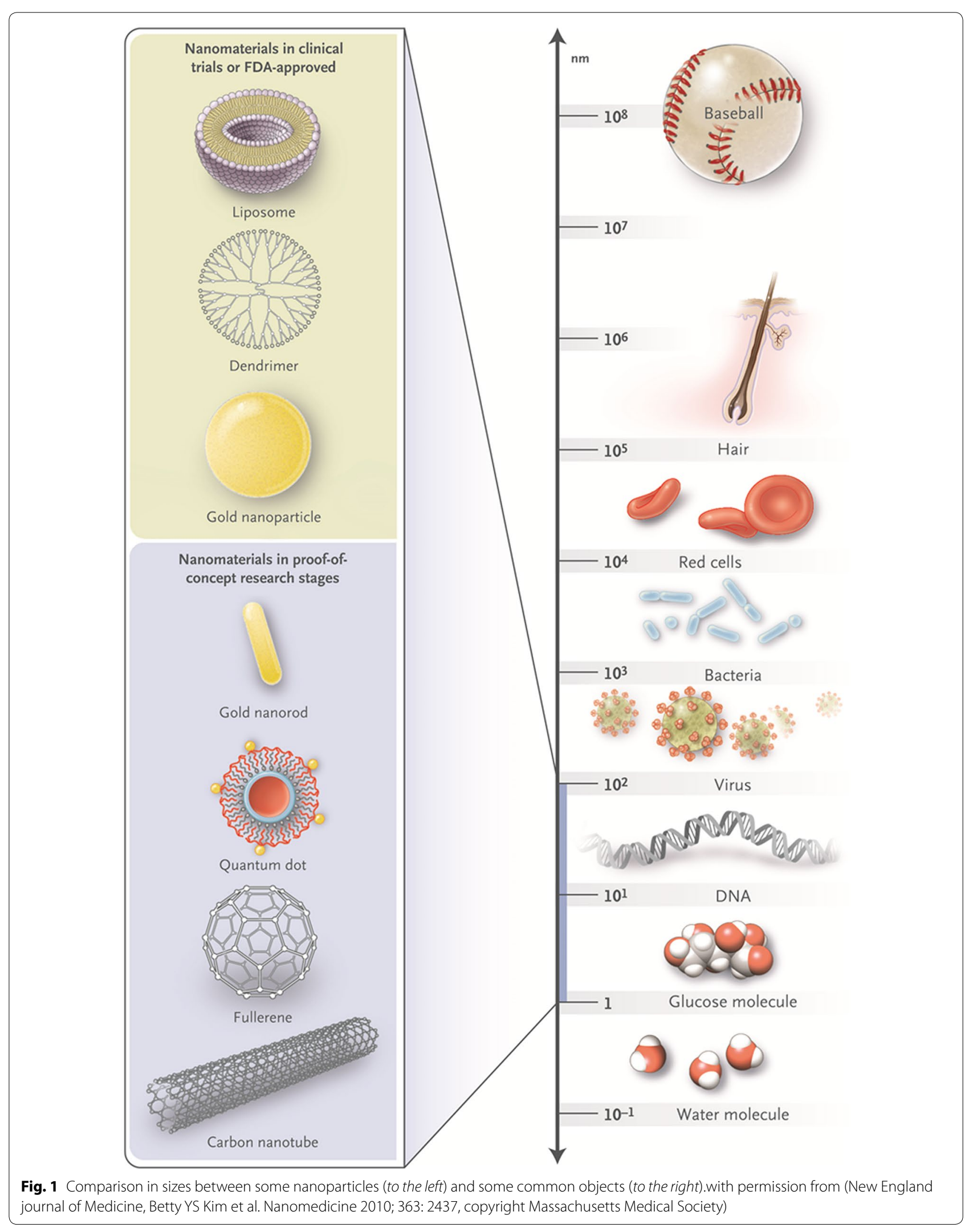




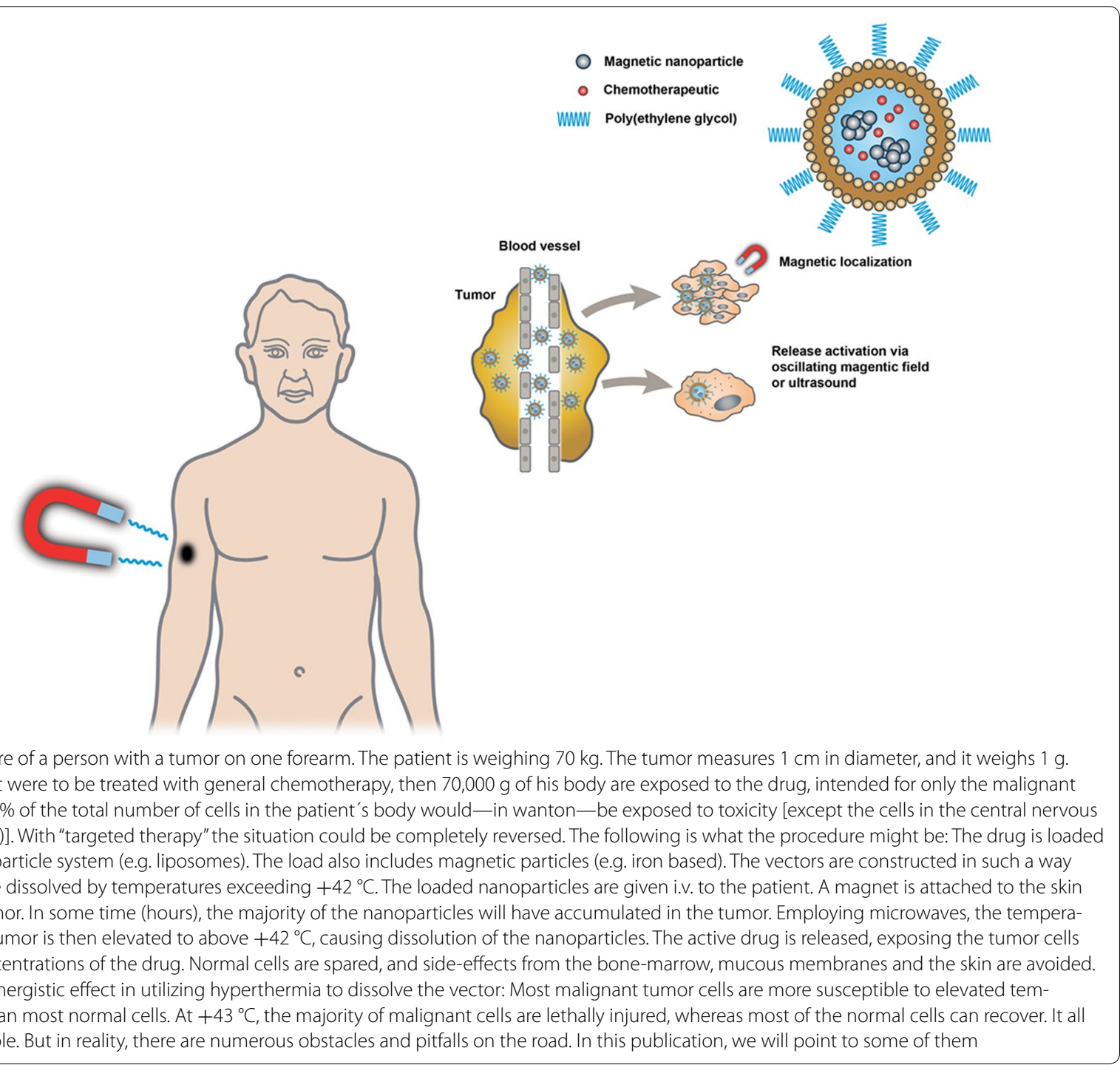

\section{Targeting of nanoparticles}

So-called targeted delivery is based on functionalization of NPs with tissue-specific ligands such as antibodies, aptamers, [162] peptides, [161, 163, 164] or small molecules [165], and have been described in numerous publications [105, 129, 136, 166-179]. Targets on human cancer cells can be extracellular receptors on the cell surfaces (receptors for transferrin, estrogen, folate [180], etc.) or intracellular receptor (telomere [181], mitochondria [182]). To clarify, in the ligand/receptor interaction, we refer to a ligand as the mobile partner attaching to the non-mobile receptor, like some structure bound to the surface of a cell. In order for any binding between ligand and target to occur, the two participants must be no further apart than a few nm [183]. At greater distances, there is no attraction. This docking is easily achieved in vitro where the medium is of very low viscosity and where there are no mechanical obstacles. In vivo, however, the situation is much more complicated. Repeatedly, it has been shown that targeting of NPs does not increase the number of particles bound to cancer cells in vivo [3, $21,28,103,104,107,111,120,134,136,139,152,182$, 184-191]. For example, immunoliposomes armed with antibodies against human epidermal receptor (HER) do not bind to cancer cells "overexpressing" HER any more than non-targeted liposomes. The potential and the value of targeting of NPs for clinical oncology have-to date-been overestimated. There are fundamental laws of physics and materials, especially in relation to diffusion, absorption, adherence, and hydrodynamics, that not even NPs can avoid [192]. The situation in vivo is considerably more complex than in vitro making results based 
on in vitro studies of questionable relevance for situations in vivo. For example "overexpression" of cellular targets is a relative term where the number of structures on the cell surface is compared between a cancer cell and its normal counterpart. The comparison is made under in vitro conditions, but again this might be giving misleading information. First, even if the cancer cells in vitro express 1000 times as many receptors as their normal counterparts do under the same conditions, the relationship might be completely reversed in vivo. Secondly, In vivo, there might be 1,000,000 times as many normal cells expressing the same receptor, all capable of capturing a targeted vector. The results from in vitro analyses have simply underestimated the complexity of the situation. The receptor for transferrin is an illustrative example.

The transferrin receptor (TfR) is exposed on the surface of proliferating cells (recent review in Daniels et al.) [193], and TfR is frequently used as the target in nanooncologic therapy. In the human body, however, there are millions of normal cells expressing very high amounts of TfR. The disease hemochromatosis is a strong and eloquent example of this. Hemochromatosis is a group of diseases characterized by abnormal storage of iron [194]. The metal, which is toxic to cells in high amounts, is stored mainly in the skin, the heart, the pancreas, and the liver-organs where TfRs are abundant [195-197]. These organs are poisoned by the metal. The patient develops diabetes, and the skin is discolored brown. These two clinical features have given the disease the nickname "bronze-diabetes". The patient usually dies from either heart or liver insufficiency. The clinical picture of hemochromatosis indicates that if a NP is targeted to TfR on the membrane of a cancer cell, and injected intravenously, the NP can be hijacked by TfR expressed in normal organs. Thus the NP is more likely to end up in a normal organ than in a malignant tumor. Aiming at cancer cells with a single surface marker (such as TfR) results in aiming at a single population in a mixture of different cell populations that are constantly changing and moving.

Even if targeting of NPs to cancer cells in vivo can be inefficient, targeting of NPs to receptors on the surfaces of cancer cells has been effective in radiologic detection of cancers in humans [198], and in a few clinical cases targeted NPs have been effective in therapy (see below, Table 3) [108, 109, 113, 198-201].

\section{The long journey}

Until the development of orally formulated nanodrugs, the intravenous route will remain the dominating route for clinical administration of nanooncologic agents. From the entry of the therapeutic NP into the host's blood circulation, the NP faces a long journey to its intended destination: the cancer cells [27, 107, 127, 186, 202]. During that journey, there are several barriers that need to be overcome. These hurdles are often neglected or disregarded in physiochemical evaluations of the future possibilities of nanotechnology to deliver agents to cancer cells. In this section, we point to a number of different obstacles during this long journey [127, 202].

\section{Hurdles on the journey \\ Blood}

While in the blood circulation, the NPs might have to circulate many times before encountering the tumor. During these circulation passes, they might be captured by macrophages as part of the reticulo-endothelial system. These scavengers are distributed mainly in the liver, the spleen, the lungs, and the bone marrow. The NPs might remain in the blood for several hours, so they must survive numerous capillary meshes (like the lungs and kidneys) where they come into close contact with the host's blood cells and vascular endothelium.

Thrombocytes-which are abundant in the blood-can capture the NPs through clotting and flocculation [68, 203]. The coagulation system can be activated within seconds to entrap the NPs. The soluble factors in the blood (lipids, proteins, immunoglobulins, enzymes, complement factors, etc.) are likely to alter the surface, the charge, and the size of the NPs by creating a so-called "corona" covering the vectors $[149,204]$. This attachment (called "opsonization") can not only alter the characteristics of the NPs, but also the rate of release of their cargo [205]. Thus even at the beginning of their journey the NPs might begin to lose their cargo (premature delivery). It has been shown, for example, that liposomes loaded with doxorubicin and administered intravenously start to leak $15 \mathrm{~min}$ after injection into the bloodstream. After $3 \mathrm{~h}$, only about $10 \%$ of the total administered doxorubicin remains inside the vector [205]. Thus, $90 \%$ of the drug is liberated into the blood where it can cause toxic side effects in the patient. After these hours in circulation, the NPs still might not even have been in contact with the first cancer cell [206]. In this specific example, this effect is similar to the normal administration of doxorubicin, and the slightly reduced release in blood is a strong contributing factor to the lower cardiotoxicity observed for liposomal doxorubicin compared to the free drug. In humans and experimental animals, $95 \%$ of injected NPs end up in normal organs (liver, spleen, lungs), and they are randomly distributed throughout the body by the blood. NPs are typically modified with polymers on their surface to reduce their protein and lipid binding and thus extend their circulation half-life in vivo [207]. This is often achieved with the aid of a hydrophilic polymer such as poly(ethylene glycol). However, the coating of the surface might interfere with the targeting ligands' ability to 
bind to their targets because the flexible polymer chains protruding from the NP surface might also block the intended ligand-receptor interaction $[208,209]$.

From the afferent blood capillary to a tumor cell, the NPs must diffuse through the ECM (interstitial transport). The ECM in a solid malignant tumor is dense, and rigid. It might take several hours for even a small NP $(<20 \mathrm{~nm})$ to diffuse a few $\mathrm{nm}$ through the ECM. Limited penetration and uneven distribution of chemotherapeutics in solid tumors represent monumental barriers to their efficacy. Even small drug molecules (such as doxorubicin and paclitaxel) remain in close vicinity to the afferent vessels. If poor penetration of small molecules is observed, the penetration of considerably larger NPs is even poorer. Stealth liposomes have been shown to remain adjacent (within $50 \mathrm{~nm}$ ) to the blood vessels even 2 days after intravenous injection [103, 111, 154-156, 210]. The intratumoral pharmacokinetics/pharmacodynamics are not known for small molecule drugs, let alone the much larger NPs. Small molecules can diffuse through the ECM, but most of them remain localized to regions immediately surrounding the blood vessels, and this leaves large areas of the tumor untouched by the drug $[107,108,111,186$, 190, 211, 212].

NPs-which are considerably larger than small molecules - can penetrate even less, and then only slowly. It might take several days for a medium-sized NP to travel from the blood vessel to a cancer cell only $200 \mu \mathrm{m}$ away. It should be noted that most NPs intended for medical use exceed $100 \mathrm{~nm}$ in size. Liposomes with a size of $150 \mathrm{~nm}$ do not spread beyond $50 \mu \mathrm{m}$ from the blood vessel [205].

Passive diffusion for an NP up to $10 \mathrm{~nm}$ in diameter through a stiff ECM is a time-consuming process, and at times impossible. This delay is in addition to the first two hurdles of the blood and the vascular wall that must be overcome before the ECM is even encountered. Every delay on the long journey can diminish the efficiency of an NP, and improving the intratumoral distribution of drugs/agents is vital for the success of nanooncology to overcome tumors in general and MDR in particular. This is not an easy task. Immunoglobulins (Ig) can serve as an example. IgG molecules $(150,000 \mathrm{kDa})$, which are $1 / 10$ the size of most medical NPs, diffuse $100 \mathrm{~nm}$ in $1 \mathrm{~h}, 1 \mathrm{~mm}$ in 2 days, and $1 \mathrm{~cm}$ in 7 months. The diffusion speed of considerably larger NPs is not going to be faster $[21,105,107,112,113,136,139,186,201,213]$.

\section{Binding site barrier}

The first NPs to extravasate create a new barrier to their subsequent followers into the ECM. Moreover, if the NPs manage to immobilize the first cancer cells they encounter, this creates a second barrier [113]. Thus it might not even be possible for NPs to reach the center of a macroscopic tumor.

\section{Attachment to the target}

When docking occurs between the ligand on the NP and the receptor on the cancer cell, the binding forces are weak and consist of secondary forces [214]. For the interaction to occur, the two participants must be no more than a few $\mathrm{nm}$ apart [183]. This is easily achieved in vitro. In vivo, however, the process is much more complicated. In addition, if the vector is targeted with a ligand for a cellular receptor, the ligand must be able to maintain its specificity after its long journey to the cancer cell [109, 134].

\section{Endocytosis}

A small molecule $(<1 \mathrm{~nm})$ can be passively internalized into cancer cells. This is not possible for NPs due to their considerably larger size (see Fig. 1). Thus, they have to enter a cell via endocytosis [199, 215-217]. For a fast-growing cell, this process it a matter of hours. For a slow-growing cell-like a human cancer cell-the whole process can take days [200, 218]. Next, transport through the cytoplasm is a life-threatening passage for an NP, and this part of the long journey is not a question of minutes, but of hours. Once, or if, the NPs reach cancer cells, they face the additional challenge of transport and metabolism inside the cells. Cytoplasmic lysosomes are capable of degrading NPs, and sometimes even rendering drugs inert.

All of today's cytotoxic drugs intended for clinical use have targets that are located inside the cells. For some gene therapy, the targets are inside yet another barrier, the nuclear membrane.

\section{Intracellular transport}

This is a complex process which has not been fully elucidated $[139,201]$. The diffusion rates of biological molecules inside of a cell depend on several factors. One of the most important factors is the size of the molecule. Small molecules of around $0.5 \mathrm{~nm}$ in diameter (like a sugar) diffuse rapidly at around $100 \mu \mathrm{m}^{2} \mathrm{~s}^{-1}$. Protein molecules $(3-5 \mathrm{~nm})$ diffuse more slowly at around $3-10 \mu \mathrm{m}^{2} \mathrm{~s}^{-1}$, whereas larger molecules (like vesicles $>10 \mathrm{~nm}$ in diameter) move at about $0.1 \mu \mathrm{m}^{2} \mathrm{~s}^{-1}$. The time needed for a $10 \mathrm{~nm}$ vesicle to traverse a cell $15 \mu \mathrm{m}$ in diameter amounts to several hours.

\section{Release of actives}

During its journey from entry into the bloodstream to the moment it reaches the first cancer cell, a major question is whether the vector has been able to retain its drug cargo 
(see "pre-mature unloading", page 10). If there is anything remaining of the drug/agent in the vector when arriving at its destination, the release from the carrier can require hours to days depending on the environmental conditions. For example, mesoporous silica NPs release only $30 \%$ of their cargo over $30 \mathrm{~h}$ even under optimal conditions [162].

\section{The final hurdle}

In addition to the hurdles described above, some genes and gene products must also pass through the nuclear membrane. The pores in the nuclear membranes are narrow gates with a mesh of polymers that act as a sieve [99, 219]. Passing these gatekeepers-which some therapeutic genes or gene products must do-is likely to be another time-consuming event. Again, because the NPs have no means of self-propulsion, passing through the pores is a slow process based on passive diffusion driven by a concentration gradient.

From the point of entry (the intravenous syringe) to the target (the cancer cell), there is a considerable distance that a therapeutic agent must travel. For a small $\mathrm{NP}$, this is a very long journey. It is also dangerous. The journey might be a bit shorter in experimental animals than in humans, but it is still a monumental task. The longer this journey takes, the greater the likelihood that the NP will be destroyed or prematurely release its cargo. A rough estimate of the time required for a NP to reach and deliver an active cargo is, at best, around $20 \mathrm{~h}$ in the human body. During that journey, how well has that NP been able to maintain its cargo, its specificity, and its integrity?

\section{Future therapeutic strategies}

Therapy against CSCs is likely to require a combination of mathematics, physics, biology, chemistry, and medicine. A short outline of future general oncologic therapy was given in the introduction of this publication. Here, we will give a more detailed sketch of tomorrow's general oncologic therapy. It is anticipated to be very complex, very personal, and very expensive. CSCs represent the prime target, but these are an elusive and moving target.

The future war on cancer will require multifunctional and multistep sequential therapy. Presented below are some possible steps:

A. Blocking of some of the MDR genes

B. Killing and removing the protecting bulk tumor cells. Just killing is not enough; the dead cells must be removed in order to expose the dormant CSCs

C. Mobilization of the CSCs by instigating them to reenter the cell cycle

D. Elimination or re-education of the now proliferating CSCs.

\section{Inventory of agents/drugs available today}

Agents/drugs capable of blocking the MDR genes. The scientific community is already in possession of drugs/ agents that can block four of the most important signaling pathways involved in MDR in cancer cell populations. Some examples are given in Table 1 . However, the potential side effects of blocking these genes are not known. It is also not known in what order they should be blocked, or for how long they must be blocked to allow for the next therapeutic step.

\section{RNA-based therapeutics}

Small non-coding RNA sequences can silence gene expression. Several types of RNA exist, but the most well-known is small interfering RNA (siRNA). Several hundred siRNAs have been identified, and each siRNA molecule has the potential to inhibit thousands of genes. Thus the therapeutic possibilities offered by siRNA are enormous [4, 25, 66, 147, 171, 184, 233-255]. siRNA can be synthesized and tailored for specific purposes, and thus these agents are incredibly versatile. However, they have weaknesses. They are unstable, immunogenic, short-lived in plasma, and only function intracellular. The half-life in serum of siRNA are between minutes to an hour, and when endocytosed via nanoparticle uptake the siRNA must be released from the endosome in order to elicit its function in the cytosol. They need a protective vector, which in most applications is an NP. siRNAs have been shown to block MDR genes over the course of 3-7 days in a fast-growing cell population and over the course of several weeks in a slow-growing population [153]. Patil et al. have shown in an in vivo mouse model

Table 1 Examples of drugs/agents capable of affecting some of the MDR genes in human cancer cells

\begin{tabular}{|c|c|c|c|}
\hline Signal chain & Blocking agents & Clinical status & Ref. \\
\hline Wnt & $\begin{array}{l}\text { siRNA } \\
\text { Curcumin/Piperin } \\
\text { Several other natural } \\
\text { products } \\
\text { Resveratrol }\end{array}$ & 35 clinical trials & [219-224] \\
\hline NOTCH & $\begin{array}{l}\text { siRNA } \\
\text { Monoclonal antibodies } \\
\text { Peptides } \\
\text { Decoys } \\
\text { Secretase inhibitors } \\
\text { Several natural com- } \\
\quad \text { pounds }\end{array}$ & 15 clinical trials & $\begin{array}{l}{[56]} \\
{[54,225]} \\
{[225]} \\
{[226]} \\
{[53]} \\
{[227]}\end{array}$ \\
\hline $\mathrm{Hgh}$ & $\begin{array}{l}\text { Cyclopamine (alkaloid } \\
\text { from plants) } \\
\text { Vismodelib } \\
\text { Cyclosporin } \\
\text { Sulforaphane (Broccoli) }\end{array}$ & $\begin{array}{l}\text { Several clinical trials } \\
\text { Clinical trials }\end{array}$ & $\begin{array}{l}{[58,228]} \\
{[229]} \\
{[58]} \\
{[230]}\end{array}$ \\
\hline NANOG & $\begin{array}{l}\text { siRNA } \\
\text { Resveratrol }\end{array}$ & Preclinical & $\begin{array}{l}{[231]} \\
{[232]}\end{array}$ \\
\hline
\end{tabular}


of drug-resistant tumor, that inhibition of tumor growth can be significant when combining paclitaxel with siRNA for the MDR1 gene coding for P-gp using a polymeric nanoparticle delivery system that also utilized a biotin as a targeting ligand. The collaboration between nanotechnology and RNA has created a new subspecialty: RNANananomedicine [256].

\section{Killing the protective bulk cells}

This is the primary goal of today's oncologic therapy. With the genes for MDR blocked, the bulk cells will hopefully be more susceptible to today's standard oncologic therapies. Thus, lower doses might be effective, thereby diminishing the side effects in the patient. What is not known is the time required for the body to eliminate the dead cancer cells [257]. This might be a time-consuming process during which time the MDR genes might have begun to function again. The necrotic cells are not likely to be removed by external means; the host's scavenger cells must do that.

\section{Instigating growth in dormant CSCs}

Once the protective bulk cells have been removed, the CSCs might have been exposed but still remain quiescent. If so, they must be triggered to re-enter the cell cycle if they are to be treatable. They can be triggered by several already existing agents (review in Wels et al.) [257] thereby becoming susceptible to therapy [87, 258].

Tumor related apoptosis-inducing ligand (TRAIL) is a transmembrane protein of the TNF (tumor necrosis factor) gene superfamily that triggers apoptosis in cancer cells, but not in normal cells [215, 247, 259, 260]. Thus it is an ideal candidate for cancer therapy. However, TRAIL lacks clinical applicability because of poor solubility in serum and an unfavorable pharmacokinetic profile. With the aid of nanotechnology, some of these disadvantages can be eliminated.

\section{Evaluation of therapeutic effect on CSC's}

Because CSCs are so rare, their elimination cannot be quantified by standard evaluation parameters such as tumor regression rates or retardation of tumor growth rates. Prolonged survival of the experimental animals is regarded as a more relevant parameter $[15,78,261,262]$. The improvement of survival is interpreted to indicate an effect on the tumors' CSCs [15, 78, 261-263].

\section{Elimination or re-education of the proliferating CSCS}

Proliferating CSCs are highly susceptible to conventional chemotherapeutic drugs $[6,149]$. Thus, they might be eliminated by low dose chemotherapy $[6,149,150]$. In addition, some of the agents that can block MDR genes (Table 1) can also eliminate CSCs. An alternative to elimination of CSCs is re-education to a differentiated and non-proliferating level. One example given by hematologists: in patients with acute myeloid leukemia (AML), the administration of vitamin A (retinoic acid) prevents a blast crisis [264].

Several of the drugs/agents in Tables 1 and 2 need protection from the host during their transport through the body, and, conversely, the host might need protection from the drug/agent. Sometimes an NP can offer that dual protection. Table 2 lists some of the in vivo experiments where NPs have improved the therapeutic efficacy of a drug or therapeutic agent. In Table 2 we included only publication where the therapeutic effect is measured prolonged survival of the experimental animals.

In addition to the examples of possibilities in Table 2 encouraging results have been published by MacDiarmid and her colleagues in Australia $[149,150]$. Their series of experiments are worth describing in detail because their results might serve as guidance for the future evolution of nanomedicine. Their experiments used bacterially derived minicells measuring $400 \mathrm{~nm}$ in diameter targeted with antibodies against cell surface structures on

Table 2 Selected examples of investigations where the anti-tumor agent was protected by an NP during transport through the body and where the antineoplastic effect was expressed prolonged survival

\begin{tabular}{|c|c|c|c|c|c|}
\hline Nanoparticle & Targeting ligand & Therapeutic agent & Tumor & Animal & Ref. \\
\hline Polymer & Biotin & Paclitaxel + tariquidar & "transformed murine" & Mice & [153] \\
\hline Polymer & None & Dox/curcumin & Four human malignancies & Mice & {$[265]$} \\
\hline Liposome & Peptide & Dox & Human neuroblastoma & Mice & {$[266]$} \\
\hline Chitosan-NP & mirRNA & Paclitaxel & Human ovarian cancer & Mice & {$[267]$} \\
\hline Polymer & Local injector & Dithiazanin & MGB & Rats & {$[268]$} \\
\hline Polymer & Abs, vs ABC G2 & Paclitaxel + siRNA & Human breast cancer & Mice & \\
\hline Polymer & None stated & Dox + Mitomyzin & Human breast cancer & Mice & {$[269]$} \\
\hline Polymer & Photodynamic and chemotherapy & Dox & Human breast cancer & Mice & [270] \\
\hline
\end{tabular}

GR growth reduction, $P S$ prolonged survival, Wt wild type 


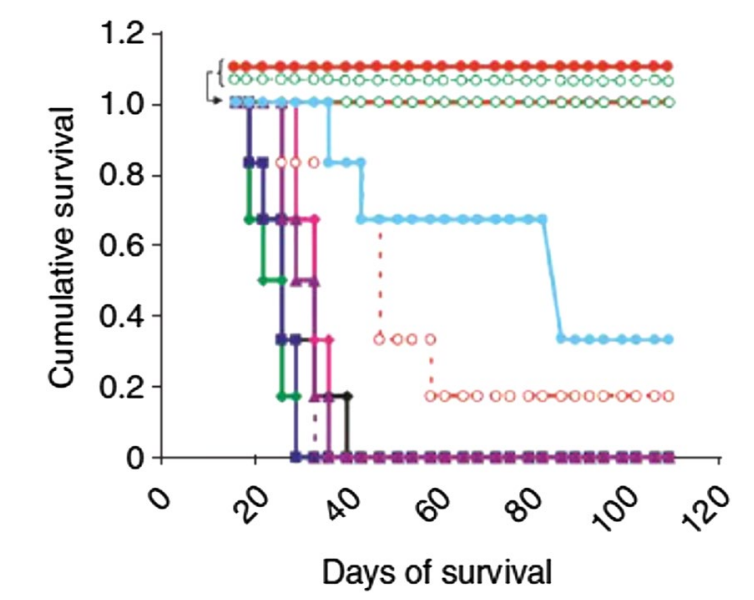

Fig. 3 Reversal of multidrug resistance in MDR1-overexpressing aggressive uterine cancer xenografts with complete survival of mice administrated dual sequential treatments. All minicell doses were administrated intravenously in nude mice with $10^{9}$ minicells per dose. The concentrations of doxorubicin or shRNA administrated per dose in $10^{9}$ minicells were 1011 copies of shRNA and $0.8 \mu \mathrm{g}$ doxorubicin. Free doxorubicin was administrated at $150 \mu \mathrm{g} /$ dose. Kaplan-Meier survival curves for the xenograft study continued for up to 120 days showing complete survival only in the MES-SA/Dx5 mice receiving sequential ${ }^{\text {EGFR Minicell }}{ }_{S S M D R 1}$ and the ${ }^{\text {EGFR Minicells }}$ Dox $_{\text {Do }}$ treatment or as expected in mice with the doxorubicin — sensitive MES-SA xenograft treated with ${ }^{\mathrm{EGFR}}$ minicells $\mathrm{s}_{\mathrm{Dox}}$. Black, Control saline, green filled,

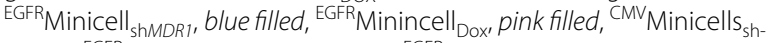
${ }_{M D R 1}+{ }^{\text {EGFRM Minicell }}$ Dox maroon filled, ${ }^{\text {EGFR Minicell }}$ shNonsenser purple hollow, $^{\text {EGFRMinicell }}{ }_{\text {shNonsense }}+{ }^{\text {EGFR Minicell }}{ }_{\text {Dox }}$ red filled ${ }^{\text {EGR Minicell }}$ ShMDR1 ${ }_{\text {EGFR Minicell }}$ oox, red hollow, ${ }^{\text {EGFR Minicell }}$ shMDR1 + free Dox, green hollow, ${ }^{\text {EGFR Minicell }}{ }_{\text {Dox' }}$ Light blue filled, Free dox

human cancer cells. Four human cancer cells lines were used: uterus sarcoma, colon cancer, colon adenocarcinoma, and breast cancer. These cells were transplanted into immunodeficient (athymic) nude mice. All four lines were fast growing with TVDTs of 10 days or less, and they were likely to produce pathological vessels thus creating the possibility of an EPR effect. Treatment was carried out in two waves. First, minicells loaded with siRNA capable of blocking the MDR genes wnt, notch, and $H g h$ were injected intravenously into the animals. With these genes blocked, the second wave of minicells was administered 2-6 days later. This time the minicells carried cytotoxic drugs, including either irinotecan, or paclitaxel, or doxorubicin, or 5-fluorouracil. The intratumoral presence of the minicells could be observed within $6 \mathrm{~h}$ after the injection of the minicells, and $30 \%$ of the drug was found in the tumors compared to only $1 \%$ when the drug was given without the targeted vector $[149,150]$. The results were astounding, and growth retardation was observed in all four cancer types and with all four cytotoxic drugs. The doses of the cytotoxic drugs were several thousand folds lower than the doses conventionally used. But even more important, survival of the animals was prolonged indicating that the CSCs in the tumor cell populations were affected. In the group of sequentially treated animals, all six mice survived over the course of the whole observation period of 110 days. In contrast, all of the animals in the control groups had succumbed in less than 50 days (Fig. 3). The critical factor in these experiments is the presence of an EPR effect in the tumors because the size of the minicells precludes transport across normal vessel walls. These results indicate that (1) targeting of NP vectors can be effective, (2) sequential therapy by blocking the genes for MDR prior to anti-neoplastic therapy makes chemotherapy against both cancer bulk cells and CSCs more effective, and (3) survival of the experimental animals is prolonged. As encouraging and exciting as these results might be, however, they still need confirmation from a second independent laboratory.

\section{Clinical cases where targeted $\mathbf{n p s}$ are considered to be effective}

In spite of all the skepticism, objections, and criticism of NPs-including the hurdles in "The long journey" (see above) - targeting of NPs against cancer cells has been successful in a few clinical cases. We have identified two reports on clinical cases where NPs were employed in the oncologic treatment and where the NPs were traced in some patients. These are summarized in Table 3.

Davis et al. conducted a phase I study (no effect variable) for treating cutaneous malignant melanoma with siRNA. Biopsies from metastases from malignant melanoma were obtained after completion of the 21 day cycle (drug given on days $1,3,8$, and 10). The siRNA was designed to suppress the messenger RNA in the malignant cells, and the siRNA in the biopsies was measured with PCR technique. The study demonstrates that siRNA systemically administrated to humans can inhibit a specific gene in a malignant tumor.

Senzer et al. conducted a phase I trial with genetic therapy (a variant of $p 53$ : SGT 53) against various malignancies. They gave the treatments twice weekly for 5 weeks, and biopsies were taken between 2 and $96 \mathrm{~h}$ after the last injection of SGT 53. Tissue samples were taken from cutaneous metastases from three patients with cutaneous malignant melanomas along with normal tissue samples. In all tumor-derived tissue, exogenous ${ }^{\mathrm{wt}}$ p53 was detected, but not in the normal tissue. These results indicate not only the tumor-targeting ability of systemically administered $p 53$, but also the specificity for tumor tissue over normal tissue. However, in Senzer et al's publication it is not possible to estimate the time required for the NP to travel from the point of administration to the tumor. 
Table 3 Reports on clinical cases where therapeutic NPs were traced in the patient

\begin{tabular}{llllll}
\hline Nanoparticle (NP) & Size of NP $(\mathbf{n m})$ & Ligand/receptor & Drug/agent & $\begin{array}{l}\text { Method to trace NP/ } \\
\text { drug/agent }\end{array}$ \\
\hline Polymer & 70 & Protein/TfR & siRNA & PCR & pef. \\
Liposome & ns & Ab/TfR & p53 & p53 via PCR & {$[236]$} \\
\hline
\end{tabular}

TfR transferrin receptor, siRNA short interfering RNA, $P C R$ polymerase chain reaction, $A b$ antibody, $p 53$ a tumor suppressor gene, ns not stated

\section{Discussion}

The question posed in the title of this article cannot yet be answered with certainty. Tomorrow's treatments of disseminated cancers face monumental obstacles, but possibilities also remain. The therapy is likely to be personalized, complicated, and expensive. The primary targets-the CSCs-are elusive, evasive, mobile, and changing. New therapeutic strategies and weapons are needed.

An overview of today's oncologic armament reveals that most of the weapons needed tomorrow already exist today. We are in possession of the drugs needed to block the genes responsible for MDR, we have the agents needed to extinguish the bulk of cancer cells, and we also have the agents needed to instigate growth in dormant cancer cells thereby making them susceptible to therapy. What is missing is knowledge of the chronological order of multistep therapies and the means of directing the active agents to their targets. Nanooncology might offer some solutions to these problems.

The versatility of this young science is very promising and has created high expectations, but several significant obstacles remain before nanomedicine can be considered practical for use in the clinic. One of the main reasons that limit the clinical translation from proof of concept of a novel nanomedicine to clinical phase testing is the matter of multifunctionality. The more complex nanomedicines that one constructs will undoubtable have a limited reproducibility in its manufacturing. An ideal drug delivery system for a MDR treatment may well include both a biological drug cargo and a more standard small molecule, packed in a nanoparticle system with a variation in size (as well as distribution of the cargo). This NP system is then further conjugated (and complicated) with a targeting moiety that allows for tissue targeting. The position and the number of available ligands on the NP surface can then also vary. In concluding such a system with three different components will have a very different composition compared to the "ideal" structure and leads to the issue of which part of this multifactorial system gives rise to the highest efficacy. This aspect is indeed very different from the situation for a small molecular "standard" drug, and this issue is a major limitation.
Nanomedicine holds much promise but there are still major areas in both basic and applied research in the area nanotechnology that needs to be explored to solve some of these problems.

Another area of specific concern is the issue of targeting the rare CSC's. Small molecular therapeutics can indeed diffuse much more efficiently than a $100 \mathrm{~nm}$ NP systems and reach both more central parts of a tumor as well as reach more metastatic sites in the body. Such sites are also often less vascularized where small and nanomedicine constructs relying on the EPR effect will not be effective.

\section{Conclusions}

Looking back at the drugs/agents available today (Tables 1, 2, 3 in this publication) that can halt or even cure various generalized cancers, the scientific community is already in possession of the weapons needed. What is missing is aiming and timing. The key is to position the right drug at the right time at the right place and at the right concentration. If this can be achieved, it will represent a major step in treating a wide array of malignancies. In summary the relevance of in vitro based results are questionable still, and tomorrows cancer treatment will need to be multifactorial with different drugs at different time points and perhaps even localized.

\section{References and notes}

Results based on in vitro studies are not included in this list. And we apologize to those researchers whose publications are not listed.

\section{Authors' contributions}

AMN and SF drafted and revised the manuscript together. All authors read and approved the final manuscript.

\section{Author details}

${ }^{1}$ Department of Neuroscience, Swedish Medical Nanoscience Center, Karolinska Institutet, Retzius väg 8, 17177 Stockholm, Sweden. ${ }^{2}$ Institute of Environmental Medicine, Karolinska Institutet, Nobels väg 13, 17177 Stockholm, Sweden.

\section{Acknowledgements}

Financial support has been provided by The Royal Swedish Academy of Sciences, Percy Falks Foundation, Swedish Research Council, Carl Bennet AB, Karolinska Institutet, and VINNOVA—Swedish Governmental Agency for Innovation Systems. 
Sten Friberg was previously at Department of Neuroscience, Swedish Medical Nanoscience Center, Karolinska Institutet, Retzius väg 8, 17177 Stockholm, Sweden and Andreas M. Nyström was previously at Institute of Environmental Medicine, Nobels väg 13, SE-171 77 Stockholm, Karolinska Institutet, Nobels väg 13, 17177 Stockholm, Sweden.

\section{Competing interests}

AM Nyström is Chief Medical Officer of Polymer Factory Sweden AB and is a shareholder in the company that is marketing dendrimers. The authors have no other relevant affiliations or financial involvement with any organization or entity with a financial interest in or financial conflict with the subject matter or materials discussed in the manuscript apart from those disclosed.

\section{Received: 31 October 2015 Accepted: 3 March 2016 Published online: 09 March 2016}

\section{References}

1. Ferlay J, et al. Cancer incidence and mortality worldwide: sources, methods and major patterns in GLOBOCAN 2012. Int J Cancer. 2015;136(5):E359-86.

2. Correia AL, Bissell MJ. The tumor microenvironment is a dominant force in multidrug resistance. Drug Resist Updat. 2012;15(1-2):39-49.

3. Gupta PB, Chaffer CL, Weinberg RA. Cancer stem cells: mirage or reality? Nat Med. 2009;15(9):1010-2.

4. Kunjachan S, et al. Multidrug resistance: physiological principles and nanomedical solutions. Adv Drug Deliv Rev. 2013;65(13-14):1852-65.

5. Polyak K, Weinberg RA. Transitions between epithelial and mesenchymal states: acquisition of malignant and stem cell traits. Nat Rev Cancer. 2009;9(4):265-73.

6. Essers MA, Trumpp A. Targeting leukemic stem cells by breaking their dormancy. Mol Oncol. 2010;4(5):443-50.

7. Maitland NJ, Collins AT. Cancer stem cells - A therapeutic target? Curr Opin Mol Ther. 2010;12(6):662-73.

8. Pattabiraman DR, Weinberg RA. Tackling the cancer stem cells - what challenges do they pose? Nat Rev Drug Discov. 2014;13(7):497-512.

9. Vinogradov $S$, Wei X. Cancer stem cells and drug resistance: the potential of nanomedicine. Nanomedicine (Lond). 2012;7(4):597-615.

10. Schatton T, Frank MH. Cancer stem cells and human malignant melanoma. Pigment Cell Melanoma Res. 2008;21(1):39-55.

11. Sell S. On the stem cell origin of cancer. Am J Pathol. 2010;176(6):2584-94.

12. Singh A, Settleman J. EMT, cancer stem cells and drug resistance: an emerging axis of evil in the war on cancer. Oncogene. 2010;29(34):4741-51.

13. Bao B et al. Overview of cancer stem cells (CSCs) and mechanisms of their regulation: implications for cancer therapy. Curr Protoc Pharmacol. 2013. Chapter 14: p. Unit 1425.

14. Chaffer CL, Weinberg RA. A perspective on cancer cell metastasis. Science. 2011;331(6024):1559-64.

15. Clevers $H$. The cancer stem cell: premises, promises and challenges. Nat Med. 2011;17(3):313-9.

16. Eyler CE, Rich JN. Survival of the fittest: cancer stem cells in therapeutic resistance and angiogenesis. J Clin Oncol. 2008;26(17):2839-45.

17. Greaves M. Cancer stem cells as 'units of selection'. Evol Appl. 2013;6(1):102-8

18. Rasheed ZA, et al. Concise review: emerging concepts in clinical targeting of cancer stem cells. Stem Cells. 2011;29(6):883-7.

19. Schatton T, Frank MH. Antitumor immunity and cancer stem cells. Ann NY Acad Sci. 2009;1176:154-69.

20. Visvader JE, Lindeman GJ. Cancer stem cells: current status and evolving complexities. Cell Stem Cell. 2012;10(6):717-28.

21. Kwon IK, et al. Analysis on the current status of targeted drug delivery to tumors. J Control Release. 2012;164(2):108-14.

22. Zhao Y, Alakhova DY, Kabanov AV. Can nanomedicines kill cancer stem cells? Adv Drug Deliv Rev. 2013;65(13-14):1763-83.

23. Longley $D B$, Johnston PG. Molecular mechanisms of drug resistance. J Pathol. 2005;205(2):275-92.
24. Holohan C, et al. Cancer drug resistance: an evolving paradigm. Nat Rev Cancer. 2013;13(10):714-26.

25. Sell S. Potential gene therapy strategies for cancer stem cells. Curr Gene Ther. 2006;6(5):579-91.

26. Griffin MF, et al. Control of stem cell fate by engineering their micro and nanoenvironment. World J Stem Cells. 2015:7(1):37-50.

27. Chauhan VP, Jain RK. Strategies for advancing cancer nanomedicine. Nat Mater. 2013;12(11):958-62.

28. Kunjachan $\mathrm{S}$, et al. Overcoming cellular multidrug resistance using classical nanomedicine formulations. Eur J Pharm Sci. 2012;45(4):421-8.

29. Omidi Y, Barar J. Targeting tumor microenvironment: crossing tumor interstitial fluid by multifunctional nanomedicines. Bioimpacts. 2014;4(2):55-67.

30. Reddy JA, Allagadda VM, Leamon CP. Targeting therapeutic and imaging agents to folate receptor positive tumors. Curr Pharm Biotechnol. 2005;6(2):131-50

31. Rothman JE. The principle of membrane fusion in the cell (Nobel lecture). Angew Chem Int Ed Engl. 2014;53(47):12676-94.

32. Schekman R, Sudhof T. An interview with Randy Schekman and Thomas Sudhof. Trends Cell Biol. 2014;24(1):6-8.

33. Al-Nedawi K, Meehan B, Rak J. Microvesicles: messengers and mediators of tumor progression. Cell Cycle. 2009;8(13):2014-8.

34. Howcroft TK, et al. Vesicle transfer and cell fusion: emerging concepts of cell-cell communication in the tumor microenvironment. Cancer Biol Ther. 2011;12(3):159-64.

35. Martins VR, Dias MS, Hainaut P. Tumor-cell-derived microvesicles as carriers of molecular information in cancer. Curr Opin Oncol. 2013;25(1):66-75

36. Rak J. Extracellular vesicles-biomarkers and effectors of the cellular interactome in cancer. Front Pharmacol. 2013;4:21.

37. Adjei IM, Blanka S. Modulation of the tumor microenvironment for cancer treatment: a biomaterials approach. J Funct Biomater. 2015:6(1):81-103.

38. Oskarsson T, Batlle E, Massague J. Metastatic stem cells: sources, niches, and vital pathways. Cell Stem Cell. 2014;14(3):306-21.

39. Teicher BA. Acute and chronic in vivo therapeutic resistance. Biochem Pharmacol. 2009;77(11):1665-73.

40. Foster SJ, Johnstone K. Pulling the trigger: the mechanism of bacterial spore germination. Mol Microbiol. 1990;4(1):137-41.

41. Lewis K. Persister cells, dormancy and infectious disease. Nat Rev Microbiol. 2007;5(1):48-56.

42. Martinoia $E$, et al. Multifunctionality of plant $A B C$ transporters-more than just detoxifiers. Planta. 2002;214(3):345-55.

43. Piddock $L J$. Understanding the basis of antibiotic resistance: a platform for drug discovery. Microbiology. 2014;160(Pt 11):2366-73.

44. Van Bambeke F, Balzi E, Tulkens PM. Antibiotic efflux pumps. Biochem Pharmacol. 2000;60(4):457-70.

45. Perry T, Batterham P, Daborn PJ. The biology of insecticidal activity and resistance. Insect Biochem Mol Biol. 2011;41(7):411-22.

46. Plowe CV, Wellems TE. Molecular approaches to the spreading problem of drug resistant malaria. Adv Exp Med Biol. 1995;390:197-209.

47. Zinzi L, et al. ABC transporters in CSCs membranes as a novel target for treating tumor relapse. Front Pharmacol. 2014;5:163.

48. Haenisch S, Werk AN, Cascorbi I. MicroRNAs and their relevance to ABC transporters. Br J Clin Pharmacol. 2014;77(4):587-96.

49. Uchino K, Ochiya T, Takeshita F. RNAi therapeutics and applications of microRNAs in cancer treatment. Jpn J Clin Oncol. 2013;43(6):596-607.

50. Nusse $\mathrm{R}$, Varmus $H$. Three decades of Wnts: a personal perspective on how a scientific field developed. EMBO J. 2012;31(12):2670-84.

51. Nusse R, Varmus HE. Wnt genes. Cell. 1992;69(7):1073-87.

52. Sharma RP, Chopra VL. Effect of the Wingless (wg1) mutation on wing and haltere development in Drosophila melanogaster. Dev Biol. 1976;48(2):461-5.

53. Takebe $\mathrm{N}$, et al. Targeting Notch, Hedgehog, and Wnt pathways in cancer stem cells: clinical update. Nat Rev Clin Oncol. 2015;12(8):445-64.

54. Espinoza I, Miele L. Deadly crosstalk: notch signaling at the intersection of EMT and cancer stem cells. Cancer Lett. 2013;341(1):41-5.

55. Morgan TH. The theory of the gene. American Naturalist. 1917:51:513-44.

56. Pannuti A, et al. Targeting Notch to target cancer stem cells. Clin Cancer Res. 2010:16(12):3141-52. 
57. Nusslein-Volhard C, Wieschaus E. Mutations affecting segment number and polarity in Drosophila. Nature. 1980;287(5785):795-801.

58. Merchant AA, Matsui W. Targeting Hedgehog — a cancer stem cell pathway. Clin Cancer Res. 2010;16(12):3130-40.

59. Xie J, et al. Targeting hedgehog signaling in cancer: research and clinical developments. Onco Targets Ther. 2013;6:1425-35.

60. Silva J, et al. Nanog is the gateway to the pluripotent ground state. Cell. 2009;138(4):722-37.

61. Chambers I, et al. Functional expression cloning of Nanog, a pluripotency sustaining factor in embryonic stem cells. Cell. 2003;113(5):643-55.

62. Gerlinger $M$, et al. Intratumor heterogeneity and branched evolution revealed by multiregion sequencing. N Engl J Med. 2012;366(10):883-92.

63. Jeter $C R$, et al. NANOG in cancer stem cells and tumor development: an update and outstanding questions. Stem Cells. 2015;33(8):2381-90.

64. Mao CP, et al. Immune-mediated tumor evolution: nanog links the emergence of a stem like cancer cell state and immune evasion. Oncoimmunology. 2014;3(7):e947871.

65. Sun $A X$, et al. NANOG: a promising target for digestive malignant tumors. World J Gastroenterol. 2014;20(36):13071-8.

66. Tanaka T, et al. Sustained small interfering RNA delivery by mesoporous silicon particles. Cancer Res. 2010;70(9):3687-96.

67. Marjanovic ND, Weinberg RA, Chaffer CL. Poised with purpose: cell plasticity enhances tumorigenicity. Cell Cycle. 2013;12(17):2713-4.

68. Creighton CJ, et al. Residual breast cancers after conventional therapy display mesenchymal as well as tumor-initiating features. Proc Natl Acad Sci USA. 2009;106(33):13820-5.

69. Al-Hajj M, et al. Prospective identification of tumorigenic breast cancer cells. Proc Natl Acad Sci USA. 2003;100(7):3983-8.

70. Dick JE. Stem cell concepts renew cancer research. Blood. 2008;112(13):4793-807.

71. Hermann PC, et al. Cancer stem cells in solid tumors. Semin Cancer Biol. 2010;20(2):77-84.

72. Lacerda L, Pusztai L, Woodward WA. The role of tumor initiating cells in drug resistance of breast cancer: implications for future therapeutic approaches. Drug Resist Updat. 2010;13(4-5):99-108.

73. McDermott SP, Wicha MS. Targeting breast cancer stem cells. Mol Oncol. 2010;4(5):404-19.

74. Quintana E, et al. Efficient tumour formation by single human melanoma cells. Nature. 2008;456(7222):593-8.

75. Sell S. Stem cell origin of cancer and differentiation therapy. Crit Rev Oncol Hematol. 2004;51(1):1-28.

76. Alison MR, Lim SM, Nicholson LJ. Cancer stem cells: problems for therapy? J Pathol. 2011;223(2):147-61.

77. Badve S, Nakshatri H. Breast-cancer stem cells-beyond semantics. Lancet Oncol. 2012;13(1):e43-8.

78. Clevers H, Loh KM, Nusse R. Stem cell signaling. An integral program for tissue renewal and regeneration: Wnt signaling and stem cell control. Science. 2014;346(6205):1248012.

79. Ghiaur G, Gerber J, Jones RJ. Concise review: cancer stem cells and minimal residual disease. Stem Cells. 2012;30(1):89-93.

80. Greaves M, Maley CC. Clonal evolution in cancer. Nature. 2012;481(7381):306-13.

81. Patel NR, et al. Nanopreparations to overcome multidrug resistance in cancer. Adv Drug Deliv Rev. 2013;65(13-14):1748-62.

82. Biddle A, Mackenzie IC. Cancer stem cells and EMT in carcinoma. Cancer Metastasis Rev. 2012;31(1-2):285-93.

83. Chang JT, Mani SA. Sheep, wolf, or werewolf: cancer stem cells and the epithelial-to-mesenchymal transition. Cancer Lett. 2013;341(1):16-23.

84. Magee JA, Piskounova E, Morrison SJ. Cancer stem cells: impact, heterogeneity, and uncertainty. Cancer Cell. 2012;21(3):283-96.

85. Tam WL, Weinberg RA. The epigenetics of epithelial-mesenchymal plasticity in cancer. Nat Med. 2013;19(11):1438-49.

86. van de Stolpe A. On the origin and destination of cancer stem cells: a conceptual evaluation. Am J Cancer Res. 2013;3(1):107-16.

87. McAllister SS, Weinberg RA. The tumour-induced systemic environment as a critical regulator of cancer progression and metastasis. Nat Cell Biol. 2014;16(8):717-27.

88. Shackleton M. Normal stem cells and cancer stem cells: similar and different. Semin Cancer Biol. 2010;20(2):85-92.
89. Hanahan D, Weinberg RA. Hallmarks of cancer: the next generation. Cell. 2011;144(5):646-74

90. La Porta CA. Thoughts about cancer stem cells in solid tumors. World J Stem Cells. 2012:4(3):17-20.

91. Schwitalla S. Tumor cell plasticity: the challenge to catch a moving target. J Gastroenterol. 2014;49(4):618-27.

92. Bissell MJ, Hines WC. Why don't we get more cancer? A proposed role of the microenvironment in restraining cancer progression. Nat Med. 2011;17(3):320-9.

93. Bissell MJ, Ram TG. Regulation of functional cytodifferentiation and histogenesis in mammary epithelial cells: role of the extracellular matrix. Environ Health Perspect. 1989;80:61-70.

94. Cukierman E, Bassi DE. The mesenchymal tumor microenvironment: a drug-resistant niche. Cell Adh Migr. 2012;6(3):285-96.

95. Dvorak HF, et al. Tumor microenvironment and progression. J Surg Oncol. 2011;103(6):468-74.

96. Hanahan D, Coussens LM. Accessories to the crime: functions of cells recruited to the tumor microenvironment. Cancer Cell. 2012;21(3):309-22.

97. Mani SA, et al. The epithelial-mesenchymal transition generates cells with properties of stem cells. Cell. 2008;133(4):704-15.

98. Pickup MW, Mouw JK, Weaver VM. The extracellular matrix modulates the hallmarks of cancer. EMBO Rep. 2014;15(12):1243-53.

99. Burke B. Nuclear pore complex models gel. Science. 2006;314(5800):766-7

100. Sleeman JP. The metastatic niche and stromal progression. Cancer Metastasis Rev. 2012;31(3-4):429-40.

101. Caldwell J, Gardner I, Swales N. An introduction to drug disposition: the basic principles of absorption, distribution, metabolism, and excretion. Toxicol Pathol. 1995;23(2):102-14.

102. Dreher MR, et al. Tumor vascular permeability, accumulation, and penetration of macromolecular drug carriers. J Natl Cancer Inst. 2006:98(5):335-44.

103. Grantab R, Sivananthan S, Tannock IF. The penetration of anticancer drugs through tumor tissue as a function of cellular adhesion and packing density of tumor cells. Cancer Res. 2006;66(2):1033-9.

104. Grantab RH, Tannock IF. Penetration of anticancer drugs through tumour tissue as a function of cellular packing density and interstitial fluid pressure and its modification by bortezomib. BMC Cancer. 2012;12:214.

105. Jain RK, Stylianopoulos T. Delivering nanomedicine to solid tumors. Nat Rev Clin Oncol. 2010;7(11):653-64.

106. Jang SH, et al. Drug delivery and transport to solid tumors. Pharm Res. 2003:20(9):1337-50.

107. Minchinton Al, Tannock IF. Drug penetration in solid tumours. Nat Rev Cancer. 2006;6(8):583-92.

108. Muchekehu R, et al. The Effect of Molecular Weight, PK, and Valency on Tumor Biodistribution and Efficacy of Antibody-Based Drugs. Transl Oncol. 2013;6(5):562-72.

109. Orcutt KD, et al. Effect of small-molecule-binding affinity on tumor uptake in vivo: a systematic study using a pretargeted bispecific antibody. Mol Cancer Ther. 2012;11(6):1365-72.

110. Stylianopoulos T, et al. Multistage nanoparticles for improved delivery into tumor tissue. Methods Enzymol. 2012;508:109-30.

111. Tannock IF, et al. Limited penetration of anticancer drugs through tumor tissue: a potential cause of resistance of solid tumors to chemotherapy. Clin Cancer Res. 2002;8(3):878-84.

112. Thurber GM, Schmidt MM, Wittrup KD. Factors determining antibody distribution in tumors. Trends Pharmacol Sci. 2008;29(2):57-61.

113. van Osdol W, Fujimori K, Weinstein JN. An analysis of monoclonal antibody distribution in microscopic tumor nodules: consequences of a "binding site barrier". Cancer Res. 1991;51(18):4776-84.

114. Marusyk A, Almendro V, Polyak K. Intra-tumour heterogeneity: a looking glass for cancer? Nat Rev Cancer. 2012;12(5):323-34.

115. Longo DL. Tumor heterogeneity and personalized medicine. N Engl J Med. 2012;366(10):956-7.

116. Hobbs SK, et al. Regulation of transport pathways in tumor vessels: role of tumor type and microenvironment. Proc Natl Acad Sci USA. 1998;95(8):4607-12

117. Matsumura Y, Maeda H. A new concept for macromolecular therapeutics in cancer-chemotherapy-mechanism of tumoritropic 
accumulation of proteins and the antitumor agent Smancs. Cancer Res. 1986;46(12):6387-92.

118. Maeda H. Vascular permeability in cancer and infection as related to macromolecular drug delivery, with emphasis on the EPR effect for tumor-selective drug targeting. Proc Jpn Acad Ser B Phys Biol Sci. 2012;88(3):53-71.

119. Maeda $\mathrm{H}$. The link between infection and cancer: tumor vasculature, free radicals, and drug delivery to tumors via the EPR effect. Cancer Sci. 2013;104(7):779-89.

120. Taurin S, Nehoff H, Greish K. Anticancer nanomedicine and tumor vascular permeability; Where is the missing link? J Control Release. 2012;164(3):265-75.

121. Greish K. Enhanced permeability and retention (EPR) effect for anticancer nanomedicine drug targeting. Methods Mol Biol. 2010;624:25-37.

122. Iyer AK, et al. Exploiting the enhanced permeability and retention effect for tumor targeting. Drug Discov Today. 2006;11(17-18):812-8.

123. Duncan R. Polymer conjugates as anticancer nanomedicines. Nat Rev Cancer. 2006;6(9):688-701.

124. Lee CC, et al. A single dose of doxorubicin-functionalized bow-tie dendrimer cures mice bearing C-26 colon carcinomas. Proc Natl Acad Sci USA. 2006;103(45):16649-54.

125. Heldin $\mathrm{CH}$, et al. High interstitial fluid pressure-an obstacle in cancer therapy. Nat Rev Cancer. 2004;4(10):806-13.

126. Friberg S, Mattson S. On the growth rates of human malignant tumors: implications for medical decision making. J Surg Oncol. 1997;65(4):284-97.

127. Nichols JW, Bae YH. Odyssey of a cancer nanoparticle: from injection site to site of action. Nano Today. 2012;7(6):606-18.

128. Netti PA, et al. Role of extracellular matrix assembly in interstitial transport in solid tumors. Cancer Res. 2000;60(9):2497-503.

129. Etheridge $M L$, et al. The big picture on nanomedicine: the state of investigational and approved nanomedicine products. Nanomedicine. 2013:9(1):1-14.

130. Webster TJ. Nanomedicine: what's in a definition? Int J Nanomedicine. 2006;1(2):115-6.

131. Wagner $V$, et al. The emerging nanomedicine landscape. Nat Biotechnol. 2006;24(10):1211-7.

132. Wicki A, et al. Nanomedicine in cancer therapy: challenges, opportunities, and clinical applications. J Controlled Release. 2015;200:138-57.

133. Cheng ZL, et al. Multifunctional Nanoparticles: cost Versus Benefit of Adding Targeting and Imaging Capabilities. Science. 2012;338(6109):903-10.

134. Allen TM, Cullis PR. Liposomal drug delivery systems: from concept to clinical applications. Adv Drug Deliv Rev. 2013;65(1):36-48.

135. Anselmo AC, Mitragotri S. An overview of clinical and commercial impact of drug delivery systems. J Control Release. 2014;190:15-28.

136. Bae YH, Park K. Targeted drug delivery to tumors: myths, reality and possibility. J Control Release. 2011;153(3):198-205.

137. Bourzac K. Nanotechnology: carrying drugs. Nature. 2012;491(7425):S58-60.

138. Couvreur P. Nanoparticles in drug delivery: past, present and future. Adv Drug Deliv Rev. 2013;65(1):21-3.

139. Crommelin DJ, Florence AT. Towards more effective advanced drug delivery systems. Int J Pharm. 2013;454(1):496-511.

140. Dong X, Mumper RJ. Nanomedicinal strategies to treat multidrug-resistant tumors: current progress. Nanomedicine (Lond). 2010;5(4):597-615.

141. Estanqueiro M, et al. Nanotechnological carriers for cancer chemotherapy: the state of the art. Colloids Surf B Biointerfaces. 2015;126:631-48.

142. Fanciullino R, Ciccolini J, Milano G. Challenges, expectations and limits for nanoparticles-based therapeutics in cancer: a focus on nano-albumin-bound drugs. Crit Rev Oncol Hematol. 2013;88(3):504-13.

143. Farokhzad OC, et al. Targeted nanoparticle-aptamer bioconjugates for cancer chemotherapy in vivo. Proc Natl Acad Sci USA. 2006;103(16):6315-20.

144. Iyer AK, et al. Role of integrated cancer nanomedicine in overcoming drug resistance. Adv Drug Deliv Rev. 2013;65(13-14):1784-802.

145. Kiessling F, et al. Nanoparticles for imaging: top or flop? Radiology. 2014:273(1):10-28.

146. Kim BY, Rutka JT, Chan WC. Nanomedicine. N Engl J Med. 2010;363(25):2434-43.
147. Kirtane AR, Kalscheuer SM, Panyam J. Exploiting nanotechnology to overcome tumor drug resistance: challenges and opportunities. Adv Drug Deliv Rev. 2013;65(13-14):1731-47.

148. Livney YD, Assaraf YG. Rationally designed nanovehicles to overcome cancer chemoresistance. Adv Drug Deliv Rev. 2013;65(13-14):1716-30.

149. MacDiarmid JA, et al. Sequential treatment of drug-resistant tumors with targeted minicells containing siRNA or a cytotoxic drug. Nat Biotechnol. 2009;27(7):643-51.

150. MacDiarmid JA, Brahmbhatt H. Minicells: versatile vectors for targeted drug or si/shRNA cancer therapy. Curr Opin Biotechnol. 2011;22(6):909-16.

151. Markman $J \mathrm{~L}$, et al. Nanomedicine therapeutic approaches to overcome cancer drug resistance. Adv Drug Deliv Rev. 2013;65(13-14):1866-79.

152. Milane $L$, et al. Multi-modal strategies for overcoming tumor drug resistance: hypoxia, the Warburg effect, stem cells, and multifunctional nanotechnology. J Control Release. 2011;155(2):237-47.

153. Patil $Y B$, et al. The use of nanoparticle-mediated targeted gene silencing and drug delivery to overcome tumor drug resistance. Biomaterials. 2010;31(2):358-65.

154. Sagnella SM, McCarroll JA, Kavallaris M. Drug delivery: beyond active tumour targeting. Nanomedicine. 2014;10(6):1131-7.

155. Scheinberg DA, et al. Conscripts of the infinite armada: systemic cancer therapy using nanomaterials. Nat Rev Clin Oncol. 2010;7(5):266-76.

156. Service RF Nanotechnology. Nanoparticle Trojan horses gallop from the lab into the clinic. Science. 2010;330(6002):314-5.

157. Shapira A, et al. Nanomedicine for targeted cancer therapy: towards the overcoming of drug resistance. Drug Resist Updat. 2011;14(3):150-63.

158. Thakor AS, Gambhir SS. Nanooncology: the future of cancer diagnosis and therapy. CA Cancer J Clin. 2013;63(6):395-418.

159. Toporkiewicz $M$, et al. Toward a magic or imaginary bullet? Ligands for drug targeting to cancer cells: principles, hopes, and challenges. Int J Nanomedicine. 2015;10:1399-414.

160. van der Meel R, et al. Ligand-targeted particulate nanomedicines undergoing clinical evaluation: current status. Adv Drug Deliv Rev. 2013;65(10):1284-98.

161. Xu X, et al. Cancer nanomedicine: from targeted delivery to combination therapy. Trends Mol Med. 2015;21(4):223-32.

162. Gao Y, et al. Controlled Intracellular Release of Doxorubicin in Multidrug-Resistant Cancer Cells by Tuning the Shell-Pore Sizes of Mesoporous Silica Nanoparticles. ACS Nano. 2011;5(12):9788-98.

163. Pearce TR, Shroff K, Kokkoli E. Peptide targeted lipid nanoparticles for anticancer drug delivery. Adv Mater. 2012;24(28):3803-22.

164. Ruoslahti E. Peptides as targeting elements and tissue penetration devices for nanoparticles. Adv Mater. 2012;24(28):3747-56.

165. Xiao Z, Farokhzad OC. Aptamer-functionalized nanoparticles for medical applications: challenges and opportunities. ACS Nano. 2012;6(5):3670-6.

166. Fojo T, Parkinson DR. Biologically targeted cancer therapy and marginal benefits: are we making too much of too little or are we achieving too little by giving too much? Clin Cancer Res. 2010;16(24):5972-80.

167. Kim SS, et al. The clinical potential of targeted nanomedicine: delivering to cancer stem-like cells. Mol Ther. 2014;22(2):278-91.

168. Kruyt FA, Schuringa JJ. Apoptosis and cancer stem cells: implications for apoptosis targeted therapy. Biochem Pharmacol. 2010;80(4):423-30.

169. Massard C, Deutsch E, Soria JC. Tumour stem cell-targeted treatment: elimination or differentiation. Ann Oncol. 2006;17(11):1620-4.

170. Peer D, et al. Nanocarriers as an emerging platform for cancer therapy. Nat Nanotechnol. 2007;2(12):751-60.

171. Gao W, et al. Progress in siRNA delivery using multifunctional nanoparticles. Methods Mol Biol. 2010;629:53-67.

172. Yap TA, et al. Envisioning the future of early anticancer drug development. Nat Rev Cancer. 2010;10(7):514-23.

173. Biddlestone-Thorpe $L$, et al. Nanomaterial-mediated CNS delivery of diagnostic and therapeutic agents. Adv Drug Deliv Rev. 2012;64(7):605-13.

174. Castro MG, et al. Gene therapy and targeted toxins for glioma. Curr Gene Ther. 2011;11(3):155-80.

175. Kievit FM, Zhang M. Cancer nanotheranostics: improving imaging and therapy by targeted delivery across biological barriers. Adv Mater. 2011;23(36):H217-47. 
176. McCubrey JA, et al. Targeting the cancer initiating cell: the ultimate target for cancer therapy. Curr Pharm Des. 2012;18(13):1784-95.

177. Nukolova NV, et al. Folate-decorated nanogels for targeted therapy of ovarian cancer. Biomaterials. 2011;32(23):5417-26.

178. Ruoslahti E, Bhatia SN, Sailor MJ. Targeting of drugs and nanoparticles to tumors. J Cell Biol. 2010;188(6):759-68.

179. Wang AZ, Langer R, Farokhzad OC. Nanoparticle delivery of cancer drugs. Annu Rev Med. 2012;63:185-98.

180. Vlashi $E$, et al. Effect of folate-targeted nanoparticle size on their rates of penetration into solid tumors. ACS Nano. 2013;7(10):8573-82.

181. Joseph I, et al. The telomerase inhibitor imetelstat depletes cancer stem cells in breast and pancreatic cancer cell lines. Cancer Res. 2010;70(22):9494-504.

182. Bertrand $\mathrm{N}$, et al. Cancer nanotechnology: the impact of passive and active targeting in the era of modern cancer biology. Adv Drug Deliv Rev. 2014;66:2-25

183. Mirny L. Cell commuters avoid delays. Nat Phys. 2008;4(2):93-5.

184. Chrastina A, Massey KA, Schnitzer JE. Overcoming in vivo barriers to targeted nanodelivery. Wiley Interdiscip Rev Nanomed Nanobiotechnol. 2011;3(4):421-37.

185. Florence AT. "Targeting" nanoparticles: the constraints of physical laws and physical barriers. J Control Release. 2012;164(2):115-24.

186. Holback H, Yeo Y. Intratumoral drug delivery with nanoparticulate carriers. Pharm Res. 2011:28(8):1819-30.

187. Mikhail AS, et al. Image-based analysis of the size- and time-dependent penetration of polymeric micelles in multicellular tumor spheroids and tumor xenografts. Int J Pharm. 2014;464(1-2):168-77.

188. Pirollo KF, Chang EH. Does a targeting ligand influence nanoparticle tumor localization or uptake? Trends Biotechnol. 2008;26(10):552-8.

189. Ruenraroengsak P, Cook JM, Florence AT. Nanosystem drug targeting: facing up to complex realities. J Control Release. 2010;141(3):265-76.

190. Waite CL, Roth CM. Nanoscale drug delivery systems for enhanced drug penetration into solid tumors: current progress and opportunities. Crit Rev Biomed Eng. 2012;40(1):21-41.

191. Wong C, et al. Multistage nanoparticle delivery system for deep penetration into tumor tissue. Proc Natl Acad Sci USA. 2011;108(6):2426-31.

192. Duncan R, Gaspar R. Nanomedicine(s) under the Microscope. Mol Pharm. 2011;8(6):2101-41

193. Daniels TR, et al. The transferrin receptor and the targeted delivery of therapeutic agents against cancer. Biochim Biophys Acta. 2012;1820(3):291-317.

194. Leitman SF. Hemochromatosis: the new blood donor. Hematology Am Soc Hematol Educ Program. 2013;2013:645-50.

195. Luck AN, Mason AB. Structure and dynamics of drug carriers and their interaction with cellular receptors: focus on serum transferrin. Adv Drug Deliv Rev. 2013;65(8):1012-9.

196. Shander A, Cappellini MD, Goodnough LT. Iron overload and toxicity: the hidden risk of multiple blood transfusions. Vox Sang. 2009;97(3):185-97.

197. Kang JO. Chronic iron overload and toxicity: clinical chemistry perspective. Clin Lab Sci. 2001;14(3):209-19 (quiz 222).

198. McCarthy JR, et al. Targeted nanoagents for the detection of cancers. Mol Oncol. 2010;4(6):511-28.

199. Biswas S, Torchilin VP. Nanopreparations for organelle-specific delivery in cancer. Adv Drug Deliv Rev. 2014;66:26-41.

200. Juweid M, et al. Micropharmacology of monoclonal antibodies in solid tumors: direct experimental evidence for a binding site barrier. Cancer Res. 1992;52(19):5144-53.

201. Mikhail AS, Allen C. Block copolymer micelles for delivery of cancer therapy: transport at the whole body, tissue and cellular levels. J Control Release. 2009;138(3):214-23.

202. Bertrand N, Leroux JC. The journey of a drug-carrier in the body: an anatomo-physiological perspective. J Control Release. 2012;161(2):152-63.

203. Chow TS. Size-dependent adhesion of nanoparticles on rough substrates. J Phys-Condensed Matter. 2003;15(2):L83-7.

204. Sahneh FD, et al. Predicting the impact of biocorona formation kinetics on interspecies extrapolations of nanoparticle biodistribution modeling. Nanomedicine (Lond). 2015;10(1):25-33.

205. Drummond DC, et al. Pharmacokinetics and in vivo drug release rates in liposomal nanocarrier development. J Pharm Sci. 2008;97(11):4696-740.
206. Nasseri B, Florence AT. Microtubules formed by capillary extrusion and fusion of surfactant vesicles. Int J Pharm. 2003;266(1-2):91-8.

207. Sun $\mathrm{G}$, et al. Facile, efficient approach to accomplish tunable chemistries and variable biodistributions for shell cross-linked nanoparticles. Biomacromolecules. 2008;9(7):1997-2006.

208. Ferrari M. Frontiers in cancer nanomedicine: directing mass transport through biological barriers. Trends Biotechnol. 2010;28(4):181-8.

209. Sanhai WR, et al. Seven challenges for nanomedicine. Nat Nanotechnol. 2008;3(5):242-4

210. Yuan F, et al. Microvascular permeability and interstitial penetration of sterically stabilized (stealth) liposomes in a human tumor xenograft. Cancer Res. 1994;54(13):3352-6.

211. Multhoff $G$, Vaupel P. Radiation-induced changes in microcirculation and interstitial fluid pressure affecting the delivery of macromolecules and nanotherapeutics to tumors. Front Oncol. 2012;2:165.

212. Tredan $\mathrm{O}$, et al. Drug resistance and the solid tumor microenvironment. J Natl Cancer Inst. 2007;99(19):1441-54.

213. Jain RK. Transport of molecules in the tumor interstitium: a review. Cancer Res. 1987;47(12):3039-51.

214. van Oss CJ, et al. Repulsiv van der Waals forces I Complete dissociation of antigen-antibody complexes by means of negative van der Waals forces. Immunol Commun. 1979;8(1):11-29.

215. Akinc A, Battaglia G. Exploiting endocytosis for nanomedicines. Cold Spring Harb Perspect Biol. 2013;5(11):a016980.

216. Gao H, Shi W, Freund LB. Mechanics of receptor-mediated endocytosis. Proc Natl Acad Sci USA. 2005;102(27):9469-74.

217. Simoes $\mathrm{S}$, et al. Cationic liposomes for gene delivery. Expert Opin Drug Deliv. 2005:2(2):237-54.

218. Paulos CM, et al. Ligand binding and kinetics of folate receptor recycling in vivo: impact on receptor-mediated drug delivery. Mol Pharmacol. 2004;66(6):1406-14.

219. Oeffinger M, Zenklusen D. To the pore and through the pore: a story of mRNA export kinetics. Biochim Biophys Acta. 2012;1819(6):494-506.

220. Gupta R, Vyas P, Enver T. Molecular targeting of cancer stem cells. Cell Stem Cell. 2009;5(2):125-6

221. Mimeault M, Batra SK. Altered gene products involved in the malignant reprogramming of cancer stem/progenitor cells and multitargeted therapies. Mol Aspects Med. 2014;39:3-32.

222. Aad G, et al. Measurement of top quark polarization in top-antitop events from proton-proton collisions at radicals $=7 \mathrm{TeV}$ using the ATLAS detector. Phys Rev Lett. 2013;111(23):232002.

223. Seino $M$, et al. Differential contribution of ROS to resveratrol-induced cell death and loss of self-renewal capacity of ovarian cancer stem cells. Anticancer Res. 2015;35(1):85-96.

224. Aad G, et al. Observation of associated near-side and away-side longrange correlations in sqrt[s(NN)] = 5.02 TeV proton-lead collisions with the ATLAS detector. Phys Rev Lett. 2013;110(18):182302.

225. Espinoza I, Miele L. Notch inhibitors for cancer treatment. Pharmacol Ther. 2013;139(2):95-110.

226. Yu SD, Liu FY, Wang QR. Notch inhibitor: a promising carcinoma radiosensitizer. Asian Pac J Cancer Prev. 2012;13(11):5345-51.

227. Magnifico A, et al. Tumor-initiating cells of HER2-positive carcinoma cell lines express the highest oncoprotein levels and are sensitive to trastuzumab. Clin Cancer Res. 2009:15(6):2010-21.

228. Lee ST, et al. Cyclopamine: from cyclops lambs to cancer treatment. J Agric Food Chem. 2014;62(30):7355-62.

229. Rudin CM. Vismodegib. Clin Cancer Res. 2012;18(12):3218-22.

230. Li Y, Zhang T. Targeting cancer stem cells with sulforaphane, a dietary component from broccoli and broccoli sprouts. Future Oncol. 2013;9(8):1097-103.

231. Huang ZJ, et al. Reduced tumorigenicity and drug resistance through the downregulation of octamer-binding protein 4 and Nanog transcriptional factor expression in human breast stem cells. Mol Med Rep. 2015;11(3):1647-54

232. Sato $M$, et al. An integrated genomic approach identifies persistent tumor suppressive effects of transforming growth factor-beta in human breast cancer. Breast Cancer Res. 2014;16(3):R57.

233. Aigner A. MicroRNAs (miRNAs) in cancer invasion and metastasis: therapeutic approaches based on metastasis-related miRNAs. J Mol Med (Berl). 2011:89(5):445-57. 
234. Burnett JC, Rossi JJ, Tiemann K. Current progress of siRNA/shRNA therapeutics in clinical trials. Biotechnol J. 2011;6(9):1130-46.

235. Chen SH, Zhaori G. Potential clinical applications of siRNA technique: benefits and limitations. Eur J Clin Invest. 2011;41(2):221-32.

236. Davis ME, et al. Evidence of RNAi in humans from systemically administered siRNA via targeted nanoparticles. Nature. 2010;464(7291):1067-70.

237. Garzon R, Marcucci G, Croce CM. Targeting microRNAs in cancer: rationale, strategies and challenges. Nat Rev Drug Discov. 2010;9(10):775-89.

238. Gavrilov K, Saltzman WM. Therapeutic siRNA: principles, challenges, and strategies. Yale J Biol Med. 2012;85(2):187-200.

239. Melo SA, Kalluri R. Molecular pathways: microRNAs as cancer therapeutics. Clin Cancer Res. 2012;18(16):4234-9.

240. Nguyen J, Szoka FC. Nucleic acid delivery: the missing pieces of the puzzle? Acc Chem Res. 2012;45(7):1153-62

241. Stege A, Kruhn A, Lage H. Overcoming multidrug resistance by RNA interference. Methods Mol Biol. 2010;596:447-65.

242. Zimmerman AL, Wu S. MicroRNAs, cancer and cancer stem cells. Cancer Lett. 2011;300(1):10-9.

243. Dong C, Ji M, Ji C. microRNAs and their potential target genes in leukemia pathogenesis. Cancer Biol Ther. 2009;8(3):200-5.

244. Garzon R, Marcucci G. Potential of microRNAs for cancer diagnostics, prognostication and therapy. Curr Opin Oncol. 2012;24(6):655-9.

245. Kanasty $R$, et al. Delivery materials for siRNA therapeutics. Nat Mater. 2013;12(11):967-77.

246. Leal JA, Lleonart ME. MicroRNAs and cancer stem cells: therapeutic approaches and future perspectives. Cancer Lett. 2013;338(1):174-83.

247. Aggarwal BB, Gupta SC, Kim JH. Historical perspectives on tumor necrosis factor and its superfamily: 25 years later, a golden journey. Blood. 2012;119(3):651-65.

248. Lujambio A, Lowe SW. The microcosmos of cancer. Nature. 2012;482(7385):347-55.

249. Miele $\mathrm{E}$, et al. Nanoparticle-based delivery of small interfering RNA: challenges for cancer therapy. Int J Nanomedicine. 2012;7:3637-57.

250. Shah K. Encapsulated stem cells for cancer therapy. Biomatter. 2013;3(1):24278

251. Shen $H$, Sun T, Ferrari M. Nanovector delivery of siRNA for cancer therapy. Cancer Gene Ther. 2012;19(6):367-73.

252. Whitehead KA, Langer R, Anderson DG. Knocking down barriers: advances in siRNA delivery. Nat Rev Drug Discov. 2009;8(2):129-38.

253. Williford JM, et al. Recent advances in nanoparticle-mediated siRNA delivery. Annu Rev Biomed Eng. 2014;16:347-70.

254. Zhong X, Coukos G, Zhang L. miRNAs in human cancer. Methods Mol Biol. 2012;822:295-306.
255. Ameres SL, Martinez J, Schroeder R. Molecular basis for target RNA recognition and cleavage by human RISC. Cell. 2007;130(1):101-12.

256. Shu Y, et al. Stable RNA nanoparticles as potential new generation drugs for cancer therapy. Adv Drug Deliv Rev. 2014;66:74-89.

257. Wels J, et al. Migratory neighbors and distant invaders: tumor-associated niche cells. Genes Dev. 2008;22(5):559-74.

258. Tse JC, Kalluri R. Waking up dormant tumors. Breast Cancer Res. 2011;13(3):310.

259. Croft M, Benedict CA, Ware CF. Clinical targeting of the TNF and TNFR superfamilies. Nat Rev Drug Discov. 2013;12(2):147-68.

260. Stuckey DW, Shah K. TRAIL on trial: preclinical advances in cancer therapy. Trends Mol Med. 2013;19(11):685-94.

261. Skidan I, Steiniger SC. In vivo models for cancer stem cell research: a practical guide for frequently used animal models and available biomarkers. J Physiol Pharmacol. 2014;65(2):157-69.

262. Waters JP, Pober JS, Bradley JR. Tumour necrosis factor and cancer. J Pathol. 2013;230(3):241-8.

263. Talmadge JE, et al. Murine models to evaluate novel and conventional therapeutic strategies for cancer. Am J Pathol. 2007;170(3):793-804.

264. Schenk T, Stengel S, Zelent A. Unlocking the potential of retinoic acid in anticancer therapy. Br J Cancer. 2014;111(11):2039-45.

265. Pramanik $D$, et al. A composite polymer nanoparticle overcomes multidrug resistance and ameliorates doxorubicin-associated cardiomyopathy. Oncotarget. 2012;3(6):640-50.

266. Loi M, et al. Novel phage display-derived neuroblastoma-targeting peptides potentiate the effect of drug nanocarriers in preclinical settings. J Control Release. 2013;170(2):233-41.

267. Piao L, et al. Lipid-based nanoparticle delivery of Pre-miR-107 inhibits the tumorigenicity of head and neck squamous cell carcinoma. Mol Ther. 2012;20(6):1261-9.

268. Zhou J, et al. Highly penetrative, drug-loaded nanocarriers improve treatment of glioblastoma. Proc Natl Acad Sci USA. 2013;110(29):11751-6.

269. Prasad $\mathrm{P}$, et al. Doxorubicin and mitomycin C co-loaded polymer-lipid hybrid nanoparticles inhibit growth of sensitive and multidrug resistant human mammary tumor xenografts. Cancer Lett. 2013;334(2):263-73.

270. Khdair A, et al. Nano particle-mediated combination chemotherapy and photodynamic therapy overcomes tumor drug resistance. J Controlled Release. 2010;141(2):137-44.

271. Senzer $\mathrm{N}$, et al. Phase I study of a systemically delivered p53 nanoparticle in advanced solid tumors. Mol Ther. 2013;21(5):1096-103.

\section{Submit your next manuscript to BioMed Central and we will help you at every step:}

- We accept pre-submission inquiries

- Our selector tool helps you to find the most relevant journal

- We provide round the clock customer support

- Convenient online submission

- Thorough peer review

- Inclusion in PubMed and all major indexing services

- Maximum visibility for your research

Submit your manuscript at www.biomedcentral.com/submit

\section{() Biomed Central}

